\title{
PENGARUH SIZE, PROFITABILITAS, LEVERAGE DAN UMUR PERUSAHAAN TERHADAP PENGUNGKAPAN TANGGUNGJAWAB SOSIAL PERUSAHAAN (Studi Empiris Pada Perusahaan Manufaktur Yang Terdaftar Di Bursa Efek Indonesia Tahun 2014-2018)
}

\author{
Ike Nur Irianti ${ }^{1}$ \\ ikeirianti97@gmail.com \\ Dr. Paulus K. Allolayuk, SE., M.Si., Ak., $\mathrm{CA}^{2}$ \\ Hastutie Noor Andriati, SE., M.Si., Ak., $\mathrm{CA}^{3}$ \\ Jurusan Akuntansi, Fakultas Ekonomi dan Bisnis Universitas Cenderawasih
}

\begin{abstract}
This research aims to obtain empirical evidence on the analysis of factors influencing The disclosure of Corporate social responsibility in manufacturing companies in Indonesia. Factors used include Size, Profitability, Leverage, and age of the company. Measurement of the corporate social responsibility disclosure Using the Global REPORTING Initiative (GRI). There are 79 items to detect the level of disclosure of corporate social responsibility.

The population of this research is all the financial data of manufacturing companies listed on IDX period 2014-2018. The sample determination method used in this study is the purposive sampling method. The samples used in this research are all manufacturing companies that publish annual and financial reports during the observation period. Total sample used in this study as much as 40 companies. The data used is secondary data from IDX. The analytical techniques used are multiple linear regression analyses.

The results of this study showed that the company size affects the disclosure of corporate social responsibility, while profitability, leverage, and the company's age do not affect the disclosure of corporate social responsibility.
\end{abstract}

Keywords : :corporate social responsibility disclosure, size, profitabiity, leverage, and company age.

\section{PENDAHULUAN}

Perusahaan dalam perkembangan bisnisnya saat ini harus lebih memberikan perhatiannya pda lingkungan sosialnya. Selain memperhatikan kepentihan manajemen dan pemilik modal, perusahaan juga diharapkan untuk dapat memberikan atensinya bagi kepentingan karyawan, konsumen, masyarakat, dan lingkungannya. Tanggungjawab sosial perusahaan menjadi wacana dan kegiatan yang banyak dilakukan oleh kalangan perusahaan di Indonesia saat ini.

Isu yang telah berkembang pada komunitas bisnis yang ada di Indonesia yaitu bidang tanggung jawab sosial perusahaan (Corporate Social Responsibility) atau yang lebih dikenal dengan singkatan CSR. Pemicu munculnya masalah CSR ialah krisis ekonomi dan era informasi yang membentuk semangat baru, transparansi, dan kesadaran sosial. Di Indonesia, praktik CSR semakin kuat terutama setelah diberlakukannya UU No.40 Tahun 2007 tentang Perseroan Terbatas (PT) pasal 1 point 3 yang menyebutkan bahwa PT yang melaksanakan bisnis di lapangan dan atau peduli dengan sumber daya alam wajib menjalankan CSR. Pentingnya pengungkapan tanggungjawab

\footnotetext{
${ }^{1}$ Alumni Jurusan Akuntansi FEB Uncen

${ }^{2}$ Dosen Jurusan Akuntansi FEB Uncen

3 Dosen Jurusan Akuntansi FEB Uncen
} 
sosial perusahaan juga didukung oleh Ikatan Akuntan Indonesia melalui Pernyataan Standar Akuntansi Keuangan (PSAK) No 1 Paragraf 9. PSAK ini menjadi titik awal perusahaan melakukan pengungkapan atas kegiatan tanggung jawab sosialnya.

Penelitian tentang pengungkapan tanggung jawab sosial perusahaan ini telah banyak dilakukan. Beberapa penelitian terdahulu, ditemukan hasil yang tidak konsisten antara peneliti satu dengan peneliti lain. Penelitian yang dilakukan (Dharmawan Krisna \& Suhardianto 2016) mengenai faktorfaktor yang mempengaruhi tingkat pengungkapan tanggung jawab sosial perusahaan sebagai variabel dependen dengan menguji pengaruh ukuran perusahaan, profitabilitas dan leverage. Walaupun hasil penelitiannya menunjukkan bahwa variabel profitabilitas dan leverage tidak berpengaruh terhadap pengungkapan tanggung jawab sosial. Akan tetapi, ukuran perusahaan justru berpengaruh positif

Hasil kajian yang dilakukan oleh (Budiman, 2015) untuk mengetahui faktor-faktor yang mempengaruhi pengungkapan tanggung jawab sosial perusahaan. Variabel independen dalam penelitian ini adalah ukuran perusahaan dan profitabilitas sedangkan pengungkapan tanggung jawab sosial perusahaan sebagai variabel dependen. Hasil penelitian menunjukkan bahwa walaupun ukuran perusahaan tidak berpengaruh terhadap pengungkapan tanggung jawab sosial perusahaan. Tetapi, profitabilitas berpengaruh terhadap pengungkapan tanggung jawab sosial perusahaan.

Perumusan masalah dalam penelitian ini yaitu 1). Apakah ukuran perusahaan berpengaruh terhadap pengungkapan tanggungjawab sosial perusahaan ?, 2). Apakah profitabilitas berpengaruh terhadap pengungkapan tanggungjawaba sosial perusahaan?, 3). Apakah leverage berpengaruh terhadap pengungkapan tanggungjawaba sosial perusahaan ?, dan 4). Apakah umur perusahaan berpengaruh terhadap pengungkapan tanggungjawab sosial perusahaan ?.

Dengan tujuan penelitian yaitu untuk membuktikan secara empiris pengaru hdari ukuran perusahaan, profitabilitas, leverage, dan umur perusahaan terhadap pengungkapan tanggungajwaba sosial perusahaan.

\section{TINJAUAN PUSTAKA}

\subsection{Teori Keagenan (Agency Theory)}

Teori Keagenaan adalah kontrak antara pemegang saham dan manajer perusahaan. Inti dari hubungan keagenan adalah adanya pemisahan antara kepemilikan dan pengendalian. Adanya kepentingan yang berbeda antara kedua pihak dapat menyebabkan konflik keagenan. Konsep Teori Keagenaan di dasari pada permasalahan agensi yang timbul ketika pengurusan sebuah perusahaan terpisah dari kepemilikannya. Perusahaan adalah sistem yang memberikan peluang bagi berbagai peserta agar berkontribusi dalam bentuk modal, keahlian serta tenaga kerja dalam rangka memaksimumkan keuntungan jangka panjang.

Peserta yang berkontribusi pada modal disebut sebagai pemilik. Peserta yang berkontribusi dalam keahlian dan tenaga kerja disebut pengelola perusahaan (agen). Keberadaan dua peserta ini (pelaku dan agen) menyebabkan timbulnya permasalahan tentang sistem yang harus di bentuk untuk menyerasikan kepentingan diantara keduannya.

\subsection{Pengungkapan Tanggungjawab Sosial}

Corporate Social Responsibility (CSR) dalam bahasa Indonesia dikenal dengan tanggungjawab sosial perusahaan adalah bentuk dari rasa peduli perusahaan pada komunitas dan lingkungan di sekitarnya. CSR adalah mekanisme bagi suatu organisasi untuk secara sukarela mengintegrasikan perhatian terhadap lingkungan dan sosial ke dalam operasinya dan interaksinya dengan stakeholders, yang melebihi tanggungjawab organisasi di bidang hukum (Reni \& Anggraini 2006). Sehingga, perusahaan dalam aktivitas operasinya tidak hanya mengikat diri pada kontrak untuk mencapai keuntungan secar finansial, tetapi juga memiliki kontrak kepada komunitas dan lingkungannya dalam pembangungan ekonomi dan sosial secara menyeluruh dan berkelanjutan. 


\subsection{Penelitian Terdahulu dan Pengembangan Hipotesis}

\section{Pengaruh Ukuran Perusahaan Terhadap Pengungakapan Tanggungajwab Sosial}

Ukuran perusahaan adalah sejumlah jumlah aktiva perusahaan (aktiva tetap, aktiva tak berwujud dan aktiva lain-lain), jumlah penjualan, atau jumlah tenaga kerja yang dimiliki perusahaan sampai akhir periode pelaporan keuangan (Sembiring, 2005). Luas pengungkapan inoforamsi perusahaan dalam laporan keuangannya di pengaruhi oleh ukuran sebuah perusahaan. Sehingga, umumnya perusahaan dengan ukuran yang besar akan lebih melakukan pengungkapan informasi yang lebih besar porsinya dibandingkan dengan perusahaan yang berukuran kecil. Perusahaan besar juga akan mengungkapkan informasi lebih banyak daripada perusahaan kecil, karena perusahaan besar tidak akan lepas resiko politis yang lebih besar dibanding perusahaan kecil.

\section{H1 : Ukuran Perusahaan berpengaruh positif terhadap pengungkapan tanggung jawab sosial perusahaan}

\section{Pengaruh Profitabilitas Terhadap Pengungkapan Tanggungjawab Sosial}

Profitabilitas merupakan suatu indikator kinerja yang dilakukan manajemen dalam mengelola kekayaan perusahaan (Agustina, 2012) Perusahaan dikatakan baik apabila memiliki tingkat profitabilitas yang tinggi. Profitabilitas merupakan suatu kemampuan perusahaan untuk menghasilkan laba agar meningkatkan nilai pemegang saham serta membuat manajemen dapat mengungkapkan CSR kepada pemegang saham. Semakin tinggi tingkat profitabilitas perusahaan maka semakin besar pengungkapan informasi sosialnya

H2 : Profitabilitas berpengaruh positif terhadap pengungkapan tanggung jawab sosialn perusahaan

\section{Pengaruh Leverage Terhadap Pengungkapan Tanggungjawab Sosial}

Perusahaan yang mempunyai proporsi utang lebih banyak dalam struktur permodalannya akan mempunyai biaya keagenan yang lebih besar. Oleh karena itu, perusahaan yang mempunyai leverage tinggi mempunyai kewajiban lebih untuk memenuhi kebutuhan informasi krediturnya (Suripto dalam Lisna Untari, 2010). makin tinggi tingkat leverage (rasio hutang/aset) semakin besar kemungkinan akan melanggar perjanjian kredit sehingga perusahaan akan berusaha untuk melaporkan laba sekarang lebih tinggi (Belkaoui dan Karpik, 1989 dalam Lisna Untari, 2010), supaya laba yang dilaporkan tinggi maka manajer harus mengurangi biaya-biaya (termasuk biaya untuk mengungkapkan pertanggungjawaban sosial).

\section{H3 : Leverage berpengaruh positif terhadap pengungkapan tanggung jawab sosial perusahaan}

\section{Pengaruh Umur Perusahaan Terhadap Pengungkapan Tanggungjawab Sosial}

Umur perusahaan merupakan faktor yang mempengaruhi kinerja perusahaan dalam mengungkapkan tanggung jawab sosialnya. Umur perusahaan menggambarkan lamanya perusahaan tersebut berdiri dan berlangsungnya aktivitas usahanya. Semakin lama perusahaan, maka masyarakat semakin banyak mengetahui informasi tentang perusahaan. Umur perusahaan membuktikan bahwa perusahaan tetap dapat bertahan dan mampu bersaing. Dengan demikian, umur perusahaan bisa dihubungkan dengan kinerja keuangan suatu perusahaan. Perusahaan yang berumur lebih tua tentunya memiliki pengalaman yang lebih banyak dan lebih mengetahui kebutuhan komitmen atas informasi tentang perusahaan daripada perusahaan yang muda atau baru saja berdiri dan beroperasi..

H4 : Umur Perusahaan berpengaruh positif terhadap pengungkapan tanggung jawab sosial perusahaan 


\subsection{Model Penelitian}

Dalam penelitian ini variabel bebas atau independen yang digunakan adalah size perusahaan, profitabilitas, leverage dan umur perusahaan sedangkan variabel terikat yang dipergunakan adalah pengungkapan tanggung jawab sosial. Model analisis penelitian dapat digambarkan sebagai berikut:

\section{Gambar 1 \\ Kerangka Pemikiran}

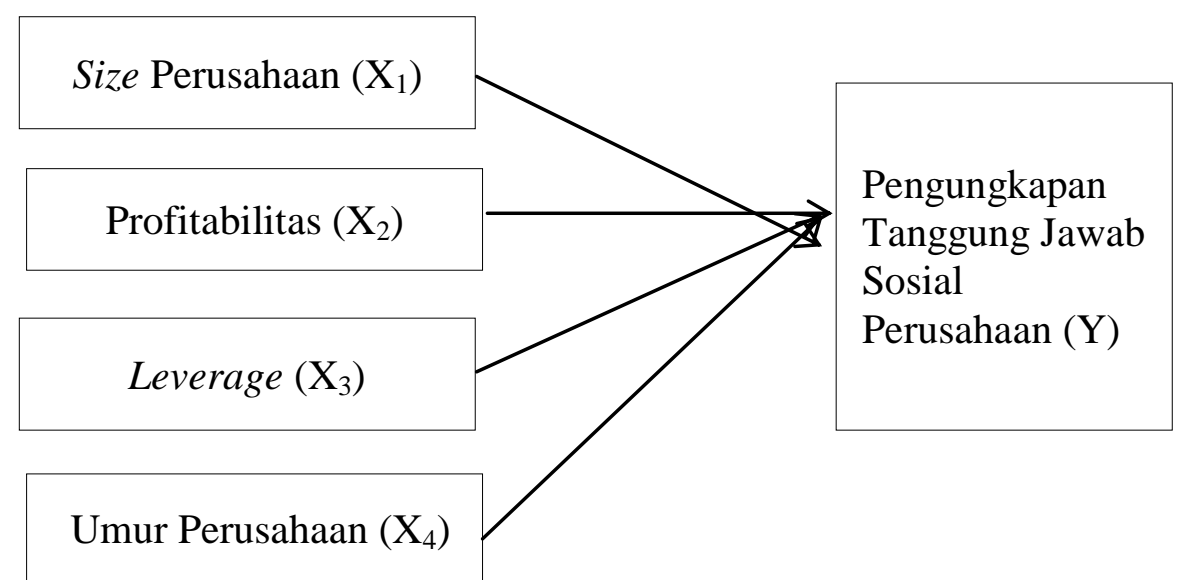

Sumber : Penulis, 2019

\section{METODOLOGI PENELITIAN}

\subsection{Jenis dan Sumber Data}

Dalam penelitian ini Jenis data yang digunakan adalah data kuantitatif. Sedangkan sumber data yang digunakan dalam penelitian ini berupa data sekunder yaitu data yang diperoleh melalui data yang tercatat berupa laporan keuangan tahunan seluruh perusahaan yang listing di bursa

efek Indonesia (BEI) selama tahun 2014 sampai dengan tahun 2018. Sedangkan sumber data yang digunakan diperoleh dari www.idx.co.id.

\subsection{Populasi dan Sampel}

Populasi adalah jumlah dari keseluruhan objek yang karakteristiknya hendak di duga. Populasi dalam penelitian ini adalah semua perusahaan manufaktur yang telah go public di Bursa Efek Indonesia (BEI) tahun 2014-2018. Sampel adalah sejumlah individu yang merupakan hasil dari populasi tersebut. Pengambilan sampel yang dilakukan dalam penelitian ini menggunakan metode purposive sampling dengan kriteria sebagai berikut :

1. Perusahaan Manufaktur yang terdapat di Bursa Efek Indonesia (BEI) sahamnya aktif diperdagangkan selama tahun 2014 -2018.

2. Perusahaan tersebut menerbitkan laporan keuangan dan laporan tahunan yang telah dipublikasikan pada tahun 2014 - 2018 secara berturut-turut.

3. Perusahaan yang memberi informasi pengungkapan sosial diungkapkan pada laporan perusahaan yang bersangkutan.

4. Menyajikan laporan keuangan dalam mata uang rupiah

5. Perusahaan Manufaktur yang memperoleh laba positif selama tahun 2014-2018. 


\subsection{Definisi Operasional dan Pengukuran Variabel Penelitian \\ Pengungkapan Tanggung Jawab Sosial Perusahaan.}

Variabel dependen dalam penelitian ini adalah Pengungkapan Tanggung Jawab Sosial Perusahaan. Pengungkapan CSR diukur dengan proksi CSRDI. Pengukuran CSRDI mengacu pada penelitian Chuzairi (2013), yang menggunakan content analysis dalam mengukur variety dari CSRDI. Pendekatan ini pada dasarnya menggunakan pendekatan dikotomi yaitu jika ada salah satu item pengungkapan CSR, maka nilai kategori tersebut diberi nilai 1, dan nilai 0 jika tidak diungkapkan. Masing-masing kategori tersebut akan dikalikan dengan jumlah indikator per kategori dan dibagi dengan jumlah keseluruhan indikator pengungkapan CSR yaitu 79 indikator.

Pengungkapan CSR $=($ Nilai K1 $\mathrm{x}$ indikator K1 + ... Nilai Kn $\mathrm{x}$ indikator Kn $) / 79$

Keterangan:

$\mathrm{K}=$ kategori pengungkapan CSR

\section{Size Perusahaan}

Size perusahaan merupakan variabel yang banyak digunakan untuk menjelaskan pengungkapan sosial yang dilakukan perusahaan dalam laporan tahunan yang dibuat. Dalam penelitian ini, peneliti menggunakan indikator pengukuran logaritma natural (total aktiva) sebagai perhitungan size perusahaan. Ukuran perusahaan yang digunakan dalam penelitian ini menggunakan besaran total asset perusahaan dengan satuan juta (Lisna Untari, 2010).

\section{Ln Size = Ln Total Aktiva}

\section{Profitabilitas (ROA)}

Kemampuan perusahaan menghasilkan laba dengan menggunakan total asset/kekayaan yang dipunyai perusahaan setelah disesuaikan dengan biaya-biaya untuk mendanai asset tersebut. Dalam penelitian ini menggunakan Return On Assets (ROA) (Lisna Untari, 2010). ROA dapat diukur dengan satuan persen.

$$
\text { ROA }=\frac{\text { Laba setelah pajak }}{\text { Total aktiva }}
$$

\section{Leverage}

Perusahaan dengan rasio leverage yang tinggi memiliki kewajiban untuk melakukan pengungkapan yang lebih luas daripada perusahaan dengan rasio leverage yang rendah. Pendapat lain mengatakan bahwa semakin tinggi leverage, kemungkinan besar perusahaan akan mengalami pelanggaran terhadap kontrak utang, maka manajer akan berusaha untuk melaporkan laba sekarang lebih tinggi dibandingkan laba di masa depan (Anggraeni, 2006 dalam Lisna Untari, 2010) .Dalam penelitian ini digunakan Leverage Ratio yaitu debt to asset ratio (DAR). Ratio Leverage dapat diukur dengan satuan kali.

$$
D A R=\frac{\text { Total hutang }}{\text { Total aktiva }}
$$

\section{Umur perusahaan}

Umur perusahaan yaitu lama perusahaan berdiri. Umur perusahaan dihitung sejak tahun perusahaan tersebut berdiri hingga perusahaan tersebut dijadikan sampel dalam penelitian. Dalam penelitian ini digunakan jumlah umur perusahaan sejak berdiri hingga akan tahun dilakukannya penelitian (Lisna Untari, 2010). Umur perusahaan diukur dengan satuan tahun. 


\subsection{Metode Analisis Data}

Analisa ini digunakan untuk menganalisis pengaruh antara variabel independen (X) yaitu size perusahaan, profitabilitas, leverage dan umur perusahaan sedangkan variabel terikat yang dipergunakan adalah pengungkapan tanggung jawab sosial. Model yang digunakan untuk menguji pengaruh variabel secara spesifik terhadap return saham dalam penelitian ini dinyatakan dalam persamaan regresi di bawah ini:

$$
\text { CSR }=\alpha+\beta 1 \text { Ln SIZE }+\beta 2 \text { ROA }+\beta 3 \text { LEV }+\beta 4 \text { AGE }+ \text { e }
$$

Keterangan :

CSR : Indeks Pengungkapan tanggung jawab sosial

Ln SIZE : Ln Total Aktiva

ROA : Return on Asset

LEV : tingkat Leverage

AGE : Umur perusahaan

$\alpha \quad$ : Konstanta

$\beta 1 \ldots \beta 4:$ Koefisien regresi

e : Error

\section{HASIL PENELITIAN DAN PEMBAHASAN}

4.1 Statistik Deskriptif

Tabel 1

Hasil Uji Statistik Deskriptif

Descriptive Statistics

\begin{tabular}{|l|r|r|r|r|r|}
\hline & N & Minimum & Maximum & \multicolumn{1}{c|}{ Mean } & Std. Deviation \\
\hline CSR & 200 &, 0127 &, 1519 &, 076203 &, 0325508 \\
SIZE & 200 & 25,6195 & 32,2010 & 28,452950 & 1,5236162 \\
ROA & 200 &, 0003 &, 4666 &, 079833 &, 0751107 \\
LEV & 200 &, 0363 &, 8436 &, 363973 &, 2004504 \\
AGE & 200 & 6,0000 & 87,0000 & 41,580000 & 17,1526871 \\
Valid N (listwise) & 200 & & & & \\
\hline
\end{tabular}

Sumber: Hasil Olah Data SPSS (2019)

\section{Pengungkapan Tanggungjawab Sosial}

Tanggung jawab sosial merupakan laporan aktivitas tanggung jawab sosial yang telah dilakukan oleh perusahaan baik yang berkaitan dengan perhatian masalah dampak sosial maupun lingkungan.

Dari hasil pengujian statistik deskriptif rata-rata pengungkapan tanggungjawab sosial perusahaan manufaktur yang terdaftar di BEI pada tahun 2014 -2018 adalah 0,76203 dengan standar deviasi 0,0325508 Pengungkapan tanggungjawab sosial paling rendah adalah 0,0127 dan paling tinggi adalah 0,1519 .

\section{Size Perusahaan}

Secara umum perusahaan besar akan mengungkapkan informasi lebih banyak daripada perusahaan kecil. Secara teoritis perusahaan besar tidak akan lepas dari tekanan politis, yaitu tekanan untuk melakukan pertanggungjawaban sosial.

Berdasarkan hasil pengujian statistik deskriptif, variabel ukuran perusahaan memiliki nilai minimum sebesar 25,6195 dengan nilai maksimum sebesar 32,2010 nilai rata rata 28,452950 serta nilai standar deviasi sebesar 1,5236162 .

\section{Profitabilitas}


Profitabilitas adalah kemampuan perusahaan untuk meraup laba bersih. Hubungan antara profitabilitas dan tingkat pengungkapan pertanggungjawaban sosial adalah bahwa ketika perusahaan memiliki tingkat laba yang tinggi, perusahaan (manajemen) menganggap tidak perlu melaporkan hal-hal yang dapat mengganggu informasi tentang sukses keuangan tersebut.

Berdasarkan hasil pengujian statistik deskriptif, variabel profitabilitas memiliki nilai minimum sebesar 0,0003 dengan nilai maksimum 0,4666 nilai rata rata 0,79833 serta nilai standar deviasi sebesar 0,751107 .

\section{Leverage}

Leverage dapat diartikan sebagai tingkat ketergantungan perusahaan terhadap hutang dalam membiayai kegiatan operasinya, dengan demikian Leverage juga mencerminkan tingkat resiko keuangan. Berdasarkan hasil pengujian statistik deskriptif, variabel leverage memiliki nilai minimum sebesar 0,363 dengan nilai maksimum 0,8436 nilai rata rata 0,363973 serta nilai standar deviasi sebesar 0,2004504

\section{Umur Perusahaan}

Umur perusahaan mengindikasikan berapa lama perusahaan tersebut berdiri dan beroperasi. Semakin lama perusahaan, maka semakin banyak informasi yang diperoleh masyarakat tentang perusahaan tersebut Sri dan Sawitri (2011).

Berdasarkan hasil pengujian statistik deskriptif, variabel umur perusahaan memiliki nilai minimum sebesar 6,000 dengan nilai maksimum sebesar 87,0000 dengan nilai rata rata 41,580000 serta nilai standar deviasi sebesar 17,1526871 .

\subsection{Uji Asumsi Klasik \\ Uji Normalitas}

Pengujian normalitas uji statistik One-Sample Kolmogrov-smirnov. Dimana jika pada nilai probabilitas signifikan $\geq 0,05$ maka data dikatakan berdistribusi secara normal. Dari hasil pengujian yang dilakukan dalam penelitian, menunjukkan bahwa data yang digunakan terdistribusi secara normal dapat dilihat pada tabel 4.3 hal ini di tandai dengan besarnya nilai kolmogrov-smirnov 1,190 pada tingkat signifikan 0,118 yang menunjukkan lebih besar dari tingkat signifikasi $0,05(0,118 \geq$ $0,05)$.

Tabel 2

\section{Hasil Uji Normalitas}

One-Sample Kolmogorov-Smirnov Test

\begin{tabular}{|c|c|c|}
\hline & & $\begin{array}{l}\text { Unstandardized } \\
\text { Residual }\end{array}$ \\
\hline $\begin{array}{l}\text { N } \\
\text { Normal Parameters }{ }^{\mathrm{a}, \mathrm{b}} \\
\text { Most Extreme Differences } \\
\text { Kolmogorov-Smirnov Z } \\
\text { Asymp. Sig. (2-tailed) }\end{array}$ & $\begin{array}{l}\text { Mean } \\
\text { Std. Deviation } \\
\text { Absolute } \\
\text { Positive } \\
\text { Negative }\end{array}$ & $\begin{array}{r}199 \\
, 0000000 \\
, 00957893 \\
, 084 \\
, 058 \\
-, 084 \\
1,190 \\
, 118\end{array}$ \\
\hline
\end{tabular}

a. Test distribution is Normal.

b. Calculated from data.

Sumber: Data diolah Peneliti (2019) 


\section{$\underline{\text { Uji Multikolonieritas }}$}

Tabel 3
Hasil Uji Multikolonieritas
Coefficients

Berdasarkan hasil analisis, tidak ada variabel independen dalam penelitian ini yang memiliki variance inflation (VIF) lebih dari sepuluh. Dengan demikian, hasil analisis menunjukkan tidak adanya masalah multikolonieritas. Variabel size perusahaan (SIZE) memiliki nilai VIF sebesar 1,340, variabel profitabilitas (ROA) memiliki nilai VIF sebesar 1,473, variabel leverage (LEV) memiliki nilai VIF sebesar 1,169, variabel ukuran perusahaan (AGE) memiliki nilai VIF sebesar 1,286.

Hasil menunjukkan bahwa semua variabel memiliki nilai toleransi lebih dari 0,10 dan nilai VIF kurang dari 10,00. Oleh karena itu dapat disimpulkan bahwa variabel independen yang digunakan dalam model regresi penelitian ini adalah terbebas dari multikolinearitas.

\section{Uji Heterokedasititas}

Uji Heterokedasititas bertujuan untuk menguji apakah dalam regresi terjadi ketidaksamaan variance residual antara satu pengamatan dengan pengamatan yang lain atau tidak. Jika variance residuan antara satu pengamatan dengan pengamatan lainnya tetap, maka disebut heterokedasititas. Adapun cara yang dapat dilakukan untuk mendeteksi heterokedasititas adalah dengan mengamati grafik scatterplot antara nilai prediksi variabel terikat (ZPRED) dengan residualnya (SRESID). Apabila ada pola tertentu seperti titik titik yang ada membentuk pola teratur (bergelombang, melebar, kemudian menyempit), maka telah terjadi Heterokedasititas. Akan tetapi, jika tidak ada pola yang jelas , serta titik titik menyebar diatas dan dibawah angka 0 pada sumbu $\mathrm{Y}$ maka tidak terjadi heterokedasititas.

\section{Gambar 2}

\section{Hasil Uji Heterokedasititas}

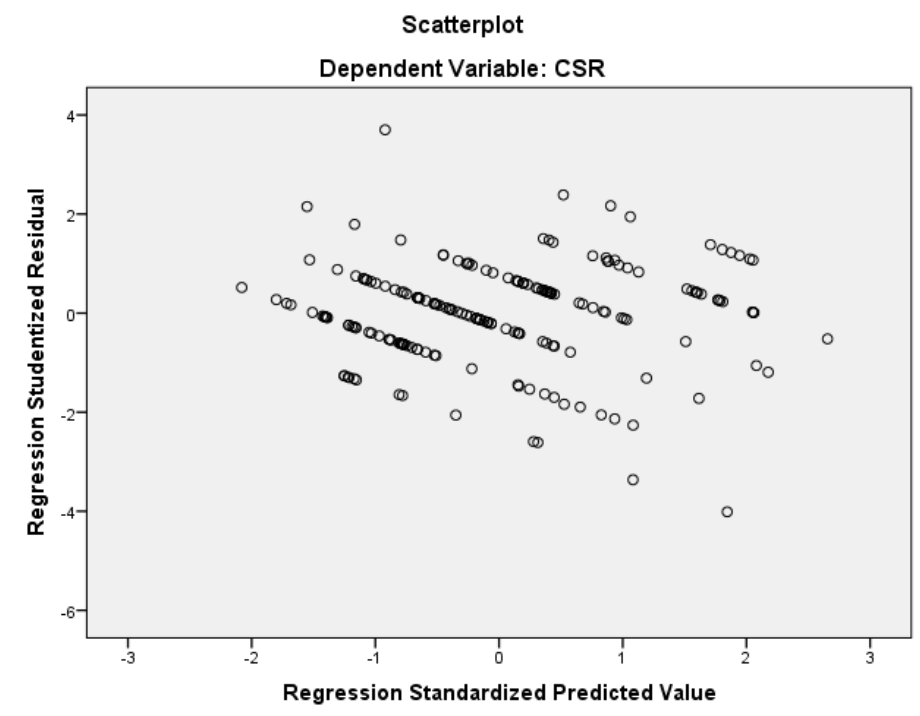


Berdasarkan gambar diatas, maka dapat disimpulkan bahwa data yang digunakan dalam penelitian ini tidak mengandung heterokedasititas atau data menyebar secara acak serta tersebar diatas maupun dibawah angka 0 pada sumbu $Y$.

\section{Uji Autokorelasi}

Uji autokorelasi digunakan untuk mengetahui apakah dalam model regresi linear ada koreksi antara kesalahan penggangu pada periode $\mathrm{t}$ dengan kesalahan penggangu pada periode $\mathrm{t}-1$. Cara mendeteksinya adalah dengan melakukan uji DW (Durbin Watson). Regresi yang bebas dari autokorelasi dengan menggunakan Durbin Watson test jika memenuhi syarat $\mathrm{du}<\mathrm{dw}<4$-du.

\section{Tabel 4}

Hasil Uji Autokolerasi
\begin{tabular}{|l|c|r|r|r|r|}
\hline Model & $\mathrm{R}$ & $\mathrm{R}$ Square & $\begin{array}{c}\text { Adjusted R } \\
\text { Square }\end{array}$ & $\begin{array}{c}\text { Std. Error of the } \\
\text { Estimate }\end{array}$ & Durbin-Watson \\
\hline 1 &, $660^{\mathrm{a}}$ &, 436 &, 421 &, 00970 & 1,984 \\
\hline
\end{tabular}
a. Predictors: (Constant), Lag_Y, AGE, LEV, SIZE, ROA
b. Dependent Variable: CSR
Sumber: Data diolah Peneliti (2019)

Berdasarkan output diatas, diketahui nilai Durbin Watson 1.984 Nilai ini akan dibandingkan dengan tabel signifikansi 5\%. Jumlah sampel $(\mathrm{N}=200)$ dan jumlah variabel independen $4(\mathrm{~K}=4)$. Maka diperoleh nilai dU 1,7279 dari tabel Durbin Watson.

Tabel 5

Pengujian Asumsi Autokorelasi

\begin{tabular}{|c|c|c|c|c|c|}
\hline Dl & $\mathbf{d U}$ & $\mathbf{4}-\mathbf{d L}$ & $\mathbf{4}-\mathbf{D u}$ & $\mathbf{D W}$ & Interprestasi \\
\hline 1,8094 & 1,7279 & 2,1906 & 2,2721 & 1,984 & $\begin{array}{c}\text { Tidak terdapat } \\
\text { autokorelasi }\end{array}$ \\
\hline
\end{tabular}

Sumber: Data diolah Peneliti (2019)

Berdasarkan hasil pengujian autokorelasi pada tabel 4.7 diatas, nilai DW 1,984 lebih kecil dari batas atas (dU) yakni 1,7279 dan kurang dari 4-dU yaitu 2,2721 Maka dapat disimpulkan bahwa hasil regresi penelitian ini tidak terjadi autokorelasi.

\subsection{Hasil Pengujian Hipotesis}

\section{Hasil Uji Koefisien Determinasi (Adjusted R2)}

Tabel 6

Hasil Uji Koefisien Determinasi (Adjusted R2)

\begin{tabular}{|l|c|c|c|c|}
\hline Model & $\mathrm{R}$ & $\mathrm{R}$ Square & $\begin{array}{c}\text { Adjusted R } \\
\text { Square }\end{array}$ & $\begin{array}{c}\text { Std. Error of the } \\
\text { Estimate }\end{array}$ \\
\hline 1 &, $660^{\mathrm{a}}$ &, 436 &, 421 &, 00970 \\
\hline
\end{tabular}

Berdasarkan tabel 4.9 diatas, nilai Adjusted $R$ Square $\left(\mathrm{R}^{2}\right)$ sebesar 0,440 yang menunjukkan bahwa hanya sebesar $42 \%$ variasi variabel dependen (CSR) yang dapat dijelaskan oleh variabel independen (size, profitabilitas, leverage dan umur perusahaan). Sedangkan sisanya $\quad(100 \%-42$ $=58 \%$ ) dijelaskan oleh variabel-variabel lain diluar model yang tidak dimasukkan kedalam penelitian yang mungkin dapat mempengaruhi pengungkapan tanggungjawab sosial perusahaan. 


\section{Uji F}

Tabel 7

Hasil Uji F

ANOVA $^{\mathrm{a}}$

\begin{tabular}{|ll|r|r|r|c|c|}
\hline Model & & Sum of Squares & \multicolumn{1}{|c|}{ Df } & Mean Square & F & Sig. \\
\hline \multirow{4}{*}{1} & Regression &, 014 & 5 &, 003 & 29,799 &, $000^{\circ}$ \\
& Residual &, 018 & 193 &, 000 & & \\
& Total &, 032 & 198 & & & \\
\hline
\end{tabular}

a. Dependent Variable: CSR

b. Predictors: (Constant), Lag_Y, AGE, LEV, SIZE, ROA

Dari hasil uji ANOVA yang ditunjukkan dalam tabel 4.9, terlihat bahwa nilai probabilitas sebesar 0,00. Karena nilai probabilitas lebih kecil dari 0,05, sehingga dapat dikatakan bahwa bahwa model dapat digunakan untuk memprediksi pengungkapan CSR.

\section{Uji t-statistik (Parsial)}

\section{Tabel 8}

\section{Hasil Uji Parsial (Uji T)}

Coefficients $^{\mathbf{a}}$

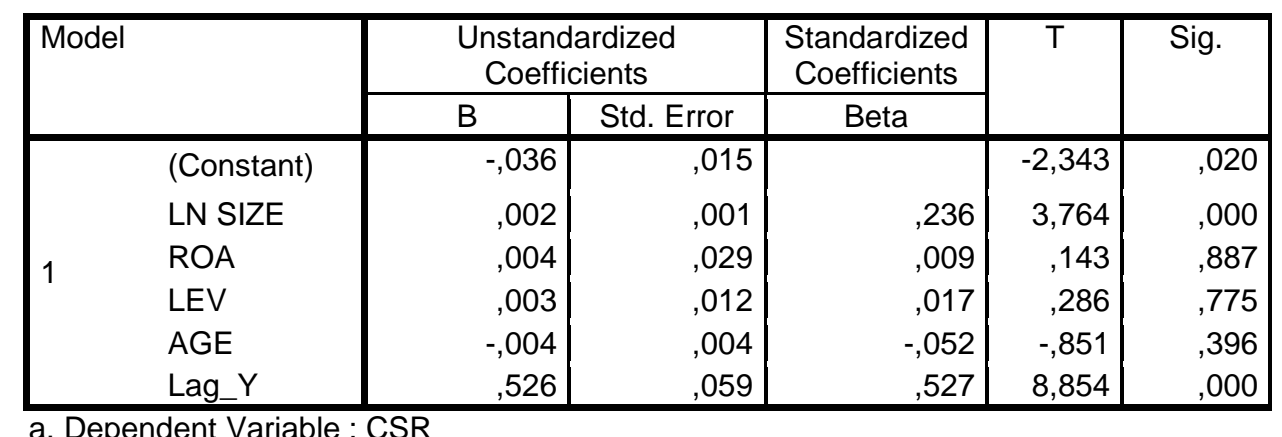

Sumber: Data diolah Peneliti (2019)

Berdasarkan tabel 4.10 menunjukan bahwa dari keeempat variabel variabel size (Ln SIZE) memiliki pengaruh signifikan, sementara profitabilitas (ROA), leverage (LEV) dan umur perusahaan (AGE) tidak memiliki pengaruh signifikan terhadap pengungkapan tanggungjawab sosial perusahaan (CSR) . Hal ini dapat dilihat sebagai berikut :

1. Hipotesis pertama $\left(\mathrm{H}_{1}\right)$ : menyatakan bahwa size perusahaan berpengaruh positif dan signifikan terhadap pengungkapan tanggungjawab sosial perusahaan.

Dari hasil pengujian regresi diperoleh nilai t hitung ukuran perusahaan sebesar 3,764 dan nilai signifikan sebesar $0,000<0,05$, maka variabel size perusahaan berpengaruh positif terhadap pengungkapan CSR pada perusahaan manufaktur yang terdaftar di BEI, berarti hipotesis pertama $\left(\mathrm{H}_{1}\right)$, diterima.

2. Hipotesis pertama $\left(\mathrm{H}_{2}\right)$ : menyatakan bahwa profitabilitas perusahaan berpengaruh positif dan signifikan terhadap pengungkapan tanggungjawab sosial perusahaan.

Dari hasil pengujian regresi diperoleh nilai t hitung profitabilitas sebesar 0,143 sebesar dan tingkat signifikan sebesar $0,887>0,05$, maka variabel profitabilitas tidak berpengaruh terhadap pengungkapan CSR pada perusahaan manufaktur yang terdaftar di BEI, berarti hipotesis kedua $\left(\mathrm{H}_{2}\right)$, ditolak.

3. Hipotesis pertama $\left(\mathrm{H}_{3}\right)$ : menyatakan bahwa leverage berpengaruh positif dan signifikan terhadap pengungkapan tanggungjawab sosial perusahaan.

Dari hasil pengujian regresi diperoleh nilai t hitung leverage sebesar 0,286 sebesar dan 
tingkat signifikan sebesar 0,775 > 0,05, maka variabel leverage tidak berpengaruh terhadap pengungkapan CSR pada perusahaan manufaktur yang terdaftar di BEI, berarti hipotesis ketiga $\left(\mathrm{H}_{3}\right)$, ditolak.

4. Hipotesis pertama $\left(\mathrm{H}_{4}\right)$ : menyatakan bahwa umur perusahaan berpengaruh positif dan signifikan terhadap pengungkapan tanggungjawab sosial perusahaan.

Dari hasil pengujian analisi regresi diperoleh nilai t umur perusahaan sebesar $-0,52$ dan tingkat signifikan sebesar 0,396 >0,05, maka variabel umur perusahaan tidak berpengaruh terhadap pengungkapan CSR pada perusahaan manufaktur yang terdaftar di BEI, berarti hipotesis keempat $\left(\mathrm{H}_{4}\right)$, ditolak.

Sehingga dengan melihat hasil analisis data understandardized coefficient pada tabel 8 maka diperoleh persamaan model regresi sebagai berikut:

$$
\begin{aligned}
\mathrm{CSR} & =\alpha+\beta 1 \mathrm{Ln} \text { SIZE }+\beta 2 \mathrm{ROA}+\beta 3 \mathrm{LEV}+\beta 4 \mathrm{AGE}+\mathrm{e} \\
& =-0,036+0,002+0,004+0,003-0,004+\mathrm{e}
\end{aligned}
$$

\subsection{Pembahasan}

\section{Pengaruh Size Perusahaan terhadap pengungkapan tanggungjawab sosial perusahaan}

Hasil regresi yang ditunjukan pada tabel 4.10 diperoleh hasil koefisien regresi untuk variabel size perusahaan sebesar 0,000 . Hal ini menunjukkan tingkat signifikannya berada dibawah 0,05 sehingga dapat disimpulkan bahwa hipotesis persamaan $\mathrm{H} 1$ diterima.

Penelitian ini sejalan dengan penelitian yang dilakukan Sembiring (2005) dan Puspitasari (2009), menemukan hasil bahwa ukuran perusahaan berpengaruh signifikan terhadap pengungkapan tanggungjawab sosial perusahaan. Beberapa penelitian terdahulu menyimpulkan bahwa perusahaan besar akan mendapatkan tekanan yang lebih besar karena aktivitasnya lebih terlihat oleh publik dibandingkan perusahaan yang lebih kecil. Sehingga untuk menjawab tekanan tersebut perusahaan melakukan pengungkapan informasi yang lebih detail terkait aktivitas operasional perusahaan.

Berdasarkan hasil penelitian diatas, maka dapat disimpulkan bahwa ukuran perusahaan berpengaruh terhadap pengungkapan tanggungjawab sosial perusahaan, Semakin besar ukuran suatu perusahaan maka tingkat pengungkapan informasinya juga akan semakin luas. Perusahaan besar cenderung mendapatkan tekanan dari publik karena aktivitasnya lebih menjadi sorotan publik dibandingkan perusahaan yang lebih kecil. Sehingga hal tersebut tentunya akan mendorong perusahaan untuk mengungkapkan informasi yang lebih detail terkait dengan ekonomi, lingkungan dan sosial dalam pengungkapan tanggungjawab sosial perusahaan.

\section{Pengaruh Profitabilitas terhadap pengungkapan tanggungjawab sosial perusahaan}

Hasil regresi yang ditunjukan pada tabel 4.10 diperoleh hasil koefisien regresi untuk variabel profitabilitas sebesar 0,887 . Hal ini menunjukkan tingkat signifikannya berada diatas 0,05 sehingga dapat disimpulkan bahwa hipotesis persamaan $\mathrm{H} 2$ ditolak.

Penelitian ini sejalan dengan Rafikia Anggraini Putri \& Christiawan (2014) Hasil dari penelitian menunjukan bahwa profitabilitas tidak berpengaruh terhadap pengungkapan CSR.

Hubungan antara profitabilitas dan pengungkapan CSR memiliki hubungan negatif karena perusahaan (manajemen) merasa tidakperlu mengungkapkan tanggung jawab sosial yang tinggi ketika perusahaan sedang memiliki tingkat profitabilitas tinggi karena perusahaan (manajemen) menganggap tidak perlu melaporkan hal-hal yang dapat menganggu informasi tentang sukses keuangan perusahaan. Sebaliknya, pada saat tingkat profitabilitas rendah, mereka berharap para pengguna laporan akan membaca "good news" kinerja perusahaan. 


\section{Pengaruh Leverage terhadap pengungkapan tanggungjawab sosial perusahaan.}

Hasil regresi yang ditunjukan pada tabel 4.10 diperoleh hasil koefisien regresi untuk variabel leverage sebesar 0,775 . Hal ini menunjukkan tingkat signifikannya berada diatas 0,05 sehingga dapat disimpulkan bahwa hipotesis persamaan $\mathrm{H} 3$ ditolak.

Penelitian ini konsisten dengan Pradnyani \& Sisdyani (2015) dalam penelitiannya bahwa Leverage tidak berpengaruh terhadap pengungkapan tanggung jawab sosial perusahaan. Perusahaan dengan leverage yang rendah mencerminkan kemampuan perusahaan pemegang saham yang baik. Sedangkan, tingkat leverage perusahaan dikatakan tinggi jika pendanaan untuk aktivitas perusahaan lebih banyak berasal dari pihak eksternal, dimana hal tersebut yang diperhatikan oleh debtholders. Untuk menimalisirkan perhatian debtholders maka manajemen perusahaan memfokuskan pada peningkatan laba sehingga luasnya pengungkapan tangggungjawab sosial dikurangi.

Hal ini disebabkan kreditur tidak terpengaruh terhadap banyaknya informasi yang diungkapkan perusahaan, salah satunya mengenai CSR, namun kreditur lebih memperhatikan kemampuan perusahaan dalam memenuhi kewajibannya.

\section{Pengaruh Umur Perusahaan terhadap pengungkapan tanggung jawab sosial perusahaan}

Hasil regresi yang ditunjukan pada tabel 4.10 diperoleh hasil koefisien regresi untuk variabel umur perusahaan sebesar 0,396. Hal ini menunjukkan tingkat signifikannya berada diatas 0,05 sehingga dapat disimpulkan bahwa hipotesis persamaan $\mathrm{H} 4$ ditolak.

Penelitian ini sejalan dengan yang dilakukan (Sunaryo \& Mahfud 2016) menyatakan bahwa umur perusahaan tidak berpengaruh terhadap pengungkapan tanggung jawab sosial.

Seiring bertambahnya umur perusahaan, maka bertambah pula tanggungjawab serta beban perusahaan. Sehingga secara tidak langsung mengurangi kemampuan perusahaan untuk melakukan pengungkapan tanggungjawab sosial perusahaan.

\section{PENUTUP}

\subsection{Kesimpulan}

Penelitian ini bertujuan untuk menganalisis pengaruh size, profitabilitas, leverage dan umur perusahaan terhadap pengungkapan tanggungjawab sosial perusahaan dalam laporan tahunan pada perusahaan manufaktur yang terdaftar di Bursa Efek Indonesia tahun 2014-2018. Analisis dilakukan dengan menggunakan analisis regresi berganda dengan program Statistical Package for Social Science (SPSS) IBM versi 21. Periode pengamatan dalam penelitian ini adalah tahun 2014-2018 dan menggunakan 40 perusahaan terpilih. Berdasarkan hasil analisis dan pengujian hipotesis, dapat dibuat kesimpulan sebagai berikut:

1. Penelitian ini membuktikan bahwa size perusahaan yang diukur dengan melogaritma naturalkan dari total aset berpengaruh terhadap pengungkapan tanggungjawab sosial perusahaan, sehingga hipotesis pertama diterima.

2. Penelitian ini membuktikan profitabilitas yang diukur dengan jumlah laba bersih dibagi dengan total aset tidak berpengaruh terhadap pengungkapan tanggungjawab sosial perusahaan, sehingga hipotesis kedua ditolak.

3. Penelitian ini membuktikan bahwa leverage yang dikukur dengan total hutang dibagi dengan total aset tidak berpengaruh terhadap pengungkapan tanggungjawab sosial perusahaan, sehingga hipotesis ketiga ditolak.

4. Penelitian ini membuktikan bahwa umur perusahaan yang diukur dengan menghitung periode tahun penelitian dikurangi tahun berdiri tidak berpengaruh terhadap pengungkapan tanggungjawab sosial perusahaan, sehingga hipotesis keempat ditolak. 


\subsection{Keterbatasan}

Adapun keterbatasan dalam penelitian ini adalah sebagai berikut:

Pada penelitian ini hanya terdapat 40 perusahaan yang memenuhi kriteria selama tahun 2014-2018.

Dan pada tahun 2018 banyak perusahaan yang tidak mempublikasikan annual report sehingga mengurangi jumlah sampel penelitian.

\subsection{Saran}

Dari keterbatasan-keterbatasan diatas maka saran yang dapat diberikan oleh peneliti adalah sebagai berikut:

1. Untuk penelitian selanjutnya, disarankan untuk menambah dan menguji variabel lain yang mungkin berpengaruh terhadap pengungkapan tanggungjawab sosial perusahaan. Misalnya kepemilikan instusional, ukuran dewan komisaris.

2. Untuk penelitian selanjutnya disarankan untuk memperluas populasi sampel seperti sektor utama dan sektor jasa.

\section{DAFTAR PUSTAKA}

Agustina, Linda. 2012. "Pengaruh Karakteristik Perushaan Terhadap Pengungkapan Laporan Tahunan." Jurnal Dinamika Akuntansi.

Budiman, Nita Andriyani. 2015. "Faktor-Faktor Yang Mempengaruhi Pengungkapan Tanggung Jawab Sosial Perusahaan." Jurnal Riset Akuntansi Mercu Buana.

Dharmawan Krisna, Aditya, And Novrys Suhardianto. 2016. "Faktor-Faktor Yang Mempengaruhi Pengungkapan Tanggung Jawab Sosial." Jurnal Akuntansi Dan Keuangan. Https://Doi.Org/10.9744/Jak.18.2.119-128.

Pradnyani, I Gusti Agung Arista, And Eka Ardhani Sisdyani. 2015. "Pengaruh Ukuran Perusahaan , Profitabilitas , Leverage, Dan Ukuran Dewan Komisaris Pada Pengungkapan Pengungkapan Tanggung Jawab Sosial Perusahaan.” E-Jurnal Akuntasi Universitas Udayana.

Putri, Rafikia Anggraini, And Yulius Jogi Christiawan. 2014. "Pengaruh Profitabilitas, Likuiditas, Dan Leverage Terhadap Pengungkapan Corporate Social Responsibility." Business Accounting Review.

Reni, Fr, And Retno Anggraini. 2006. "Pengungkapan Informasi Sosial Dan Faktor-Faktor Yang Mempengaruhi Pengungkapan Informasi Sosial Dalam Laporan Keuangan Tahunan ( Studi Empiris Pada Perusahaan-Perusahaan Yang Terdaftar Bursa Efek Jakarta ).” Simposium Nasional Akuntansi Ix Padang. Https://Doi.Org/10.1177/0007650314564783.

Sunaryo, Bustan Arya, And Mohammad Kholiq Mahfud. 2016. "Pengaruh Size, Profitabilitas, Leverage Dan Umur Terhadap Pengungkapan Tanggungjawab Sosial Perusahaan (Studi Empiris Perusahaan Manufaktur Yang Listing Di Bei Tahun 2010 - 2013).” Diponegoro Journal Of Management. 